\title{
Similarities in Pentecostal and traditional African culture: a positive potential in a context of urbanization and modernization
}

\author{
R Ingram ${ }^{1}$ \\ (University of Pretoria)
}

Similarities in Pentecostal and traditional African culture: a positive potential in a context of urbanization and modernization

\section{ABSTRACT}

This article reflects the findings of a study that was conducted by NOVA (a research organization for the alleviation of poverty) for CDE (the Centre of Development and Enterprise) in 2004 with regard to the potential contribution of Pentecostalism to the socioeconomical well-being of people who are effected by the forces of modernization and urbanisation in South Africa. The case study was conducted among Pentecostal congregations in Witbank with special focus on congregations who serve people who have recently moved from the rural areas to Witbank. We made the interesting discovery that Pentecostal congregations do not serve as a new spiritual and social home for these new-comers by accident, but because their are underlying cultural similarities between Pentecostalism and Traditional African Culture. These similarities pertain to cosmology, social structure, personhood, morality and the value of esthetical experience. Because of these similarities Pentecostal communities create a context in which people who move from the rural areas to the city may feel at home and in which they are protected from the strange and confusing environment that is the city.

In March 2004 NOVA (a research organization for the alleviation of poverty) was approached by Dr. Clinic from the Centre for Development and Enterprise to do a case-study on a couple of Pentecostal congregations in one of the urban areas of South Africa for the benefit of Prof Peter Berger at Boston University. In various previous studies on Pentecostal congregations in South America and India, Prof. Berger and his partners found that Pentecostal congregations are generally more effective than their mainline counterparts in addressing the social issues that arises from the

1 Research fellow, ISWEN, University of Pretoria. 
processes of urbanization and modernization. The purpose of our case study was to find information that would indicate whether or not this is also the case in South Africa, and to show whether or not further research on this subject would be necessary in this country. This article is based on the investigation we conducted in this regard during the winter and spring of 2004.

\section{GOAL, CONTEXT, SCOPE AND STRATEGY}

The goal of our investigation was to answer two questions:

1. Does South African Pentecostal congregations contribute in an unique way to the social integration of their members in the context of modernization? And if this were to be the case, what is the nature of this unique contribution? In answering this question we allowed ourselves to be guided by Professor Berger's conception of modernization. He defined this phenomenon as the "... progressive weakening, if not destruction, of the concrete and relatively cohesive communities in which human beings have found solidarity and meaning throughout most of history" (Berger 1977:103). Our general question could therefore more specifically be stated in the following manner: In what unique way does Pentecostal congregations assist their members to experience social solidarity and meaning in a context where traditional communities are being destructed?

2. In what unique way does Pentecostal congregations contribute towards the economical wellbeing of their members? We included this question because of NOVA's interest in poverty alleviation. The purpose was to establish the potential of Pentecostals for participating in projects pertaining to economical development.

We chose to conduct our investigation in Witbank for three different reasons. Firstly, Witbank is exemplary of the process of urbanization and modernization. It is known as a place of mines and industry, and a rapidly expanding informal settlement bares witness to the fact that there is a large influx of people into Witbank from the rural areas. Secondly, we found that Witbank (with a population of 350 000) was large enough to be exemplary of the complexities of contemporary South African urban society, yet small enough to enable us to establish a general understanding of these complexities. Thirdly, because Witbank is currently experiencing urbanisation, we 
were able to study the process of modernization as it is happening. One of the local ministers describe the situation as follows:

In the rural areas people live in a tight community. People don't need to struggle alone and people also don't need to decide and do things on their own. The policy is that you are your brother's keeper. People take responsibility for giving one-another guidance. When people come to Witbank they suddenly have to fend for themselves. It is like breaking up an ant colony.

If Pentecostals played any significant role with regard to providing solidarity to their members in a context of modernization, Witbank would be an ideal place for them to enact and demonstrate this role.

Initially we tried to keep the scope of our investigation as broad as possible. We chose research partners which are racially and socio-economically representative of the community. These included one predominantly white and one black congregation of the Apostolic Faith Mission (AFM) and one white and one black congregation of the Members in Christ Church (MICC). Except for these Pentecostal congregations, we also involved two congregations from the reformed tradition, including one black URC and one predominantly white DRC congregation. The purpose of this choice was to establish a point of reference against the background of which the peculiarities of the Pentecostal congregations could become apparent. For this purpose we also involved one African Independent Church (AIC).

Our research strategy was qualitative and comparative in nature. We gathered insights into the activities and experiences of the different congregations by means of individual interviews with pastors and knowledgeable outsiders, and by means of group discussions with members of the various congregations. The activities and experiences of the different cultural, socio-economic and denominational groups were then compared with one-another with the purpose of establishing the unique characteristics of each group. Since our purpose was only to gather interesting information that would legitimatize and inspire further investigations on this subject, we didn't find it necessary to engage in quantitative investigations.

\section{THE STORY OF OUR UNDERSTANDING}

Our first step was to compare the socio-economical contexts of the various congregations. As might have been expected, people from 
the white congregations were generally more settled with regard to housing and financial income than the people from the black congregations. The most interesting finding was however that people from the URC are socio-economically more settled than people from the MICC and AFM. This phenomenon was not only reflected by the various church leaders' perceptions of their own and one-another's situations, but also by the fact that most URC members live in the older part of KwaQuqa (the main township of Witbank), while most AFM and MICC members live in the growing informal settlement and the area where RDP houses were built during the past decade. Furthermore, while the URC minister said that more or less half of the members of his congregation have stable middle class occupations as teachers, police officers and state officials, the Pentecostal pastors said that their members were mostly employed as temporary unschooled labourers or were not working at all. This information suggest that new-comers to Witbank - people who have recently moved from the rural areas and who have not yet established themselves in the city - more often find a home with the Pentecostal congregations than with the Reformed congregation.

With regard to the social and economical activities of our research partners, we initially did not find many dissimilarities between Pentecostal and Reformed (as well as black and white) congregations. On the surface these congregations seemed very much the same. All of them supported one-another by gathering together in smaller groups, visiting one-another when they are in need and by experiencing communion during church services. Both Pentecostal and Reformed congregations have programs for developing people's technical skills with the purpose of creating jobs and encouraging entrepreneurship. All the congregations involved tried to develop the life-skills of their members by inviting knowledgeable people to talk about practical themes like how to manage one's money properly and about how to establish healthy family relationships. All the congregations had structures in place for helping their poorer members. Everybody seemed to think that the propagation of conversion and good moral values contributes towards better socio-economical circumstances.

In the initial stage of our investigation only two uniquely Pentecostal practices became obvious. We also found that these peculiarities were prominent in both the black and the white Pentecostal congregations, while they were not practiced in either 
the white or black reformed congregations. The most interesting of these was the practice of religious rituals with the specific purpose of ensuring economical or social success. Some of these rituals merely consisted of the blessing of job application papers, while others involved a symbolic enactment of a desired outcome. If someone needed a home, for example, the pastor would give that person a key, and say: "Here are your keys. Unlock your house." The person would then use the keys to unlock an imaginary house. It is then believed that such a person would receive a home in some way or another.

The other peculiarity is the practice of only assisting those people who attend church services. In both the black and white MICC congregations it is official policy to only hand out food, clothes and other favours to those people who have a stable relationship with the congregation. In the AFM, food packages are only handed out after church services in order to ensure that only those who attend church are helped. The reason given for these practices was that only people who become Christians and who consequently live according to Christian morality, can really become emancipated from poverty and all the social evils which go with it. It seemed as though these Pentecostals try to help people by making them part of their congregations. The DRC and URC congregations we encountered have no problem with helping people who do not have any relationship with their congregations at all. They see their help as a witness to the world, and they do not think that it is necessary for people to change their life-style and religious persuasion before they are helped.

These were not the only clues we were able to gather. At the very beginning of our investigation we talked to a certain local medical doctor who were involved with the URC and various Pentecostal churches, and who had strong views pertaining to the dynamics and differences between Pentecostal and Reformed Christians. He said that “... there is a huge exodus of young Christians from the URC to various Pentecostal Churches ....” According to him the reason for this development is that the African Traditional World View (ATWV) is still prominent in the lives of most black people. For the African person the spiritual world is very real, and very real problems arise from the belief in evil spirits, curses and bad luck. The Pentecostal churches offer Christian solutions to these problems, while the Reformed church merely deny 
their existence. He said that "black people like this attitude of the Pentecostal churches.”

This information put the dissimilarities we perceived among Pentecostal and Reformed congregations in an interesting light. The doctor's remark implied that black people were moving away from the Reformed denomination towards a denomination which is more accommodating towards African culture. This may also explain why people who move to Witbank from the rural areas rather find a home in Pentecostal congregations than in the URC. Could the two peculiar Pentecostal practices we observed in some way be related to African culture? We knew that at least one of these practices could very well be. The practice of enacting the outcome of an event one desires, in the hope that that event will indeed come to pass, is generally known among anthropologists under the name of "imitative magic." "Imitative magic" is illustrated by practices such as rainmaking which consists of rainmakers spitting water into the air. "Imitative magic" is also known to be a traditional African religious practice (Crafford 1996:102).

This encouraged us to think about whether or not the second peculiarity we observed could also be related to African culture. In African culture the nature of an individual is constituted by the nature of the community to which he or she belongs (Nsamenang 1999:29). The implication of this perspective is that a good and healthy individual is someone who belongs to a good and healthy community. This perspective would therefore make good sense of the Pentecostal philosophy that it is only worthwhile to help people who are part of their community. The individual can only overcome socio-economical problems by becoming a person of good virtue. And, in order to become a person of good virtue, such an individual must become part of a virtuous community. Surely Pentecostal congregations see themselves as virtuous communities. More than one Pentecostal pastor tried to convince us that they do not have people in their congregation who have very serious socioeconomical problems. The reason they usually gave for this is that the members of their congregations have moral and healthy lifestyles.

We found that there was one tricky difficulty with this line of reasoning. The practice of religious rituals to ensure success and the tendency to help needy people by encouraging them to join your 
group, was not only limited to the black Pentecostal congregations we investigated. This phenomenon placed some serious doubts in our minds with regard to the idea that the Pentecostal congregations we studied were influenced by African culture. We therefore thought that the similarities we found between Pentecostalism and African culture - interesting as they may be - could only be an irrelevant coincidence. Our minds changed however when our attention was drawn to the work of W Hollenweger - an expert on the Pentecostal movement. According to Hollenweger (1974:18) Pentecostalism originated at the hands of black Americans, and by implication at the hands of people who themselves have their roots in African culture. Maybe white people picked up these aspects of African culture when they became Pentecostals. Suddenly the parallels between African culture and the peculiar Pentecostal practices that presented themselves, seemed to be more than a mere coincidence.

Surely this evidence was not enough to allow the conclusion that Pentecostalism participate in African culture. It did however allow the hypothesis that Pentecostalism might have certain commonalities with traditional African culture. In the light of the original purpose of our investigation, we wondered whether that Pentecostal congregations may in this way contribute towards social solidarity among black people moving from the rural areas to Witbank. We were also interested in the impact that possible differences between the Pentecostal and African world view would have on these new-comers. It was of course possible that the African culture of the rural people influenced, or were expressed through, the Pentecostal congregations in Witbank, with the implication that Pentecostalism, as such, did not have any real impact. On the other hand, a persistent prominence of African ideas among white Pentecostals would point in the direction that Pentecostalism was inherently continuous with African culture.

\section{IN DIALOGUE WITH PENTECOSTALS AND AFRICANS}

The purpose of this phase of our investigation was to explore our new hypothesis that Pentecostalism contributed towards social solidarity amongst new-comers in Witbank, because it has certain continuities with African culture. Our purpose was not to try and prove this hypothesis but to record statements, attitudes and values which could legitimize a comprehensive study that would properly test this hypothesis. Non of the statements, attitudes and values we 
discuss below can be seen as being conclusive in themselves, but when viewed together they do make a strong case for the suggestion that there are strong correlations between Pentecostalism and traditional African culture.

In illuminating these correlations our reading on African culture and religion was guided by our discussions with the people who participated in our investigation. And, the questions we asked these people were guided by literature on African culture and religion. Except for black Pentecostals we also engaged in discussion with white Pentecostals in order to ensure that the ideas we found amongst black Pentecostals were truly Pentecostal in nature. We also kept interviewing people from Reformed and African Independent congregations with the purpose of establishing a point of reference that would allow any uniquely Pentecostal ideas to stand out more clearly.

For the sake of comprehensibility we systemised the main moments of clarity we gained under three headings, namely: cosmology; esthetical experience; social structure; morality; and personhood.

\subsection{Cosmology}

According to African cosmology the central property of the universe is a vital force (amandla in Zulu), which is to be found in the whole cosmos. Theron (1996:2) calls this an impersonal power, which could also be described by the anthropological term, "mana." According to Anyanwu (1981:86-87) this, however, is a Western misconception. He maintains that African culture makes selfhood the centre of the cosmos, so that every experience of reality for the African is personal. The African personalizes the experience of this vital force, so that the world is experienced as having its own personality, including feelings, thoughts, beliefs, hopes and will (Anyanwu 1981:164-165). Traditional African thought does not know the Western distinction between the profane sphere of everyday life and the sacral sphere in which transcendent divine reality is occasionally met. The tendency in traditional Africans cosmology is to "sacralise" the world (Crafford 1996:5). The everyday world is viewed as filled with personal spiritual forces, as opposed to the Western notion that the world is a material mechanism devoid of spirits and gods. In this sacral world 
interaction between human beings and divine spirits is an everyday and normal experience.

This perspective is illustrated in the way that some African businesspeople approach the management of their businesses. One of the questions we asked small business owners during in a survey of small businesses in KwaQuqa, pertained to where they would go for help and advice when their businesses are struggling. Most of those owners who belong to Pentecostal or African Independent churches said that they would go to their religious leaders. Their favourite solution to problems pertaining to their enterprises was to get a pastor or other kinds of religious leaders to come and bless their businesses. It was also common practice for some of these people to pay religious leaders to come and bless their businesses. Westerners would rather pay financial advisors or other knowledgeable people to help when their businesses get into trouble. The tendency in Western culture is to separate business life from church life. Among these Pentecostal businessmen, however, business life is a normal part of church life.

The "sacralising" tendency is not restricted to black Pentecostals, while the distinction between the sacral and profane spheres of life could also be observed among black people from the Reformed tradition. A group of URC members, for example, ascribed the practice of blessing businesses to pure superstition. When we asked questions pertaining to people's reasons for starting businesses we received the following answers from a white AFM member and a reverent from the URC:

Our current occupation was proving to be a dead end. At the same time I was reading the Dreamgiver by Wilkinson. In this book there is a passage about how one should be as free as a feather in the hands of the Lord. I also at the time had the feeling that God was telling me to leave our work, even though I did not yet know what else I was going to do. I would lose our security and benefits if I left our work, and I was very hesitant to comply with what I felt the Lord wanted me to do. I was praying about this at the time when I read the book. And one morning when I woke up, there was a feather on the book in front of our bed. To me the message was clear. If you do not trust the Lord, you cannot let go and be as light as a feather in the hands of the Lord. 
So I resigned from our job, and soon afterwards I started our own business. This is now doing very well (white AFM member).

Business is a risky thing, and people are very careful about it. If something goes wrong, you will lose the bit of money you invested in it. Yes, I think it is fear of that which is unfamiliar. And if you are jobless, you try to use the money you have as sparingly as possible, so you don't take chances with it. There also is the factor of a lack of knowledge. How do I start a business? (URC reverent).

While the Pentecostal Christian's motivation for starting her own business was purely related to her interaction with spiritual forces, the reformed Christian neglected to mention any religious reason for his congregation's hesitancy to start their own businesses.

Another traditional African way of interacting with the spiritual world is by calling in the help of experts with regard to the spiritual world for using magic (Crafford 1996:12). Magic can be used to promote life (e.g. like rain, the fertility of the field, or in modern society at sport or in exams). Magic can help to guard property, ensure safe journeys, health or luck, and to counter the effects of destructive magic. There is also the belief that "like produces like" or that "the effect resembles the cause." So for instance, a rainmaker may spit water on the ground to imitate the falling of the rain, or one may hurt the image of a person in order to harm him (Theron 1996:101-102). In the Pentecostal view, reality can also be effected by participating in it through the use of magic. The magical belief that "like produces like" is especially obvious in the practice of "manifestations" in the MICC. This practice is based on the assumption that the symbolic performance of the contents of a desire bring about the realisation of that desire. One MICC member described this practice like follows:

It is when somebody for instance needs a car, and then the pastor will give him a key and say: Take your key, and make as if you are driving your car. Then that person will get a car. Manifestations can also work in a negative way, like in the case of voodoo dolls, or when somebody curse you by putting things in your yard. Then these people get power over you. My mother was almost killed by something like this (MICC member).

The presence of magical practices may also be discerned in the blessing job application papers and businesses. Traditionally 
ceremonies were performed to ensure the fertility of the fields, but in modern society the goal of these practices is often to ensure success in modern activities like exams and (as in the case relevant to our investigation) the acquisition of a job or the success of a business.

Another cosmological correlation between the traditional African world view and Pentecostalism may be seen in the fact that some Pentecostals understanding of the Holy spirit has much in common with the African conception of life-force. In African cosmology the being of entities is relative to the life force or spirit they possess. Their existence is relative to their having force, and it is believed that the failure or success of a person depends on the amount of force he or she possesses (Ruch 1981:149; Anyanwu 1981:169; Theron 1996:2). In the African view whatever force a person acquires is given to him by superior beings who possess this force. In the some Pentecostals' view the Holy Spirit seems to have more in common with African amandla (life-force) than with the third person of the trinity. When we asked a group of members of the MICC to explain their understanding of the Holy Spirit, we received a definition which was almost exactly the same as the definition scholars give of amandla:

The Spirit is like some kind of force. It is an energy force that empowers the believer. When you are filled with the Spirit, you can act strongly and do anything (MICC members).

The Pentecostals also see their personal capabilities as being dependent on the Spirit within them. People who possess the Spirit can make right decisions, recognize opportunities and persevere through difficulties which will overwhelm people who don't possess the Spirit.

\subsection{Esthetical experience}

The spirituality of the Pentecostal congregations we encountered is focused on the emotional experience of community with one-another and with God through the Holy Spirit, while the spirituality of reformed Christians is focused on learning and the conceptual content of faith. This phenomenon is illustrated by the different ways in which Pentecostal and Reformed Christians experience their participation in the Sunday services of their congregations.

I feel the power of the Holy Spirit, and I feel connected with God and with our brothers and sisters who are with me (MICC members: 20/06/2004). 
The church taught me that God is the only one that can save. I learn a lot at church, and I feel cared for (URC member: 09/06/2004).

The traditional African perspective that the cosmos is a fundamental unity of a single divine force which penetrates everything. Africans strive to participate in the harmony of this fundamental cosmological unity. This "harmony" towards which Africans strive, can be described as "... an aesthetic concept-feeling which expresses the solution to the opposite poles of experience" (Anyanwu 1981:274). It is through the imaginative projection of art, like dance and music, that the African experiences the meaning of the cosmos as a harmonious spiritual unity (Anyanwu 1981:272).

The world-view created by the African art or by the African mind-set is that of aesthetic qualities and continuum where contradictions and oppositions form a unitary whole. In this kind of world, there are no fixed and static forces. All are reducible to motion, sound, rhythm and dynamism and these qualities permeate the African soul or life-force, overflow his thought, feelings and environment. Since the self is not dissociated from the world, since the observer-observed are inseparable, the idea of art or music refers to an integrated sensibility. Musical instruments, drummers, singers, composers, dancers, spectatorparticipants and ultimately the universe of life-force constitute the idea of music (Anyanwu 1981:279).

For the Western mind the truth is something that can be conceptualised and understood intellectually. For the African the truth is something that must be experienced emotionally.

The focus in both the black and white Pentecostal Sunday service is not on the conceptual content of the song and sermon, but rather on the experience of the music, the dance and the tone of the preacher's voice. In the Sunday services of the MICC congregations we investigated we sang short songs over and over again, while the rhythm provided by the drummers was very prominent and the rhythmic clapping of hands reminded of a crowd who was encouraging their team. In one particular service I was sitting against a wall and our back was touching the metal tubing of an electrical wire. The music played very loudly through the large speakers, so that the vibration of the electrical tubing reflected the vibrant music and intense emotion. The style of the preaching was also interesting. 
The preacher would start gently with a point, and then talk louder and louder, encouraging the people to join in with encouraging remarks of their own. It was as if he was trying to move the congregation with the sound of his voice, rather than with the content of his message. This is also true for the way the pastors and their congregations - prayed. They would start gently and then speak louder and louder, more and more intense, as though they were capable of moving God with the sound of their voice.

Pentecostals describes their experiences of these rollicking church services as follows:

I feel the power of the Holy Spirit, and I feel connected with God and with our brothers and sisters who are with me (MICC member: 20/06/2004).

Yes, when you experience God in church you get strength and power, so that you can face any problem (MICC member: 20/06/2004).

One of the speakers during the service of the black MICC congregation said: "We are blessed because we dance and sing, and we enjoy God." In this statement God is spoken of in a very impersonal way. It reminds of Anyanwu's (1981:279) remark that Africans experience the power of the life-force - which originates in God, but which also is in everything and every-one - through music.

\subsection{Social structure}

The church structures of Pentecostal churches are more hierarchical than that of reformed churches. In the case of the former authority rests with the hierarchy of pastors, while in the latter it resides in the church council. This is reflected in the fact that one must get permission from the pastor - or even the senior pastor when there are more than one pastor - when one wants to study a Pentecostal congregation, while one must communicate with the church council in the case of Reformed congregations. It also goes hand in hand with the phenomenon that the members of reformed congregations are more involved with the management of congregations. The pastors of both the black and white MICC congregations who participated in our research project expressed their dismay with the fact that the members of their congregations expects them to do everything. On the other hand, the URC minister who worked with us, repeatedly expressed his gratitude towards the members of his 
congregation who do most of the management of the congregation without his help.

The lack of member's participation with regard to the management of Pentecostal congregations probably reflects the general subordination of these members to the authority and autonomy of their pastors. In the Pentecostal congregations the pastors usually decide what is right and wrong on behalf of their church members. Some Pentecostal pastors even propagate this approach explicitly.

The culture of our denomination is such, that people simply follow the instructions of the pastors. Traditionally people in our denomination don't like to ask critical questions, they want definite and clear instructions. They feel that it is wrong to reason about things. One must believe like a child. They don't like grey areas. They get uncomfortable when things are not clear. They feel safe when they simply knows something to be a yes or a no (MICC pastor).

In the reformed congregations members have much more freedom to form their own opinions with regard to important issues. Pentecostal church members would for example repeatedly express the same negative views of their pastors with regard to ancestor worship, while some members of the URC rejected some of their pastors view's in his presence.

Such a hierarchical social structure is also prominent with traditional African society.. The spiritual world is understood as consisting of a hierarchy of spiritual forces (Crafford 1996:12). Also people share in this force. People exists as an expression of spiritual forces (Ruch 1981:149; Anyanwu 1981:169; Theron 1996:2). In this way the hierarchy of spiritual forces comes to expression in the form of a hierarchical society. One respects this hierarchy of forces, by showing respect to one's seniors or ancestors, and by not stepping out of one's allotted place in the hierarchy (Theron 1996:4).

\subsection{Personhood}

In Pentecostal congregations people's identity is a more social or public matter than in the case of reformed churches. This is demonstrated by the practice in some Pentecostal congregations of revealing people's sins and confessions publicly. In the reformed churches people's sins and problems is treated as a very private matter, while Pentecostal congregations encourage their members to 
confess their sins publicly and often expose people's sins and problems in public. This tendency is reflected in the following statements by a Pentecostal and reformed Christian with regard to their experiences of how sins and problems are treated in their congregations.

In the DRC some people go to church, but they still drink, smoke and swear when they are at work. I do not like that at all. One must walk one straight path. I also like the fact that we have prophets in our congregation. They will expose your sins before everybody. Therefore I am afraid of sin, and this is a good thing (MICC member).

We are very strict with regard to confidentiality. Even on the notes of the meetings of our committees who deal with these problems we don't mention the names of people (DRC member).

In the first statement a strong relationship is drawn between morality - not doing sin - and the possibility that the congregation might find out about it. It is the possibility of exposure that is identified as the main motivation for acting in a particular way. One's relationship to God or inner conviction are not mentioned as reasons for acting in a certain way.

In Pentecostal congregations it is not only the morality of a person which is directed by the community. A person's identity is also determined by his or her deeds and performance which is discernable within the public sphere of the congregation. Pastor Johan Mocke, previously a Pentecostal pastor but now a Baptist minister, expresses this phenomenon as follows:

People in the Pentecostal churches see their own value as something that is determined by your participation in church services, by your performance and by what you do. Here we see a person's value as something that is determined by what the scripture says about a person, and not as something to be gained by what a person does (Baptist minister).

This perspective also becomes clear when one compare the following answers that were given by a Pentecostal and a reformed church member respectively to a question pertaining to what determines a Christian's identity: 
I also think that a Christian's identity is determined by what he or she does. You are what you do. People who smoke marijuana for instance cannot be Christians (AFM member).

You get people who think that their salvation and identity as a Christian is dependent on their deeds, but we do not teach this. Good deeds flow from thankfulness about one's salvation. And, the deeper your faith, the better the deeds that flow from it (DRC member).

In Pentecostal congregations a Christian's identity is determined by his or her deeds and performance which can be observed by other people. In reformed churches people's identity is seen as dependent on a person's faith and on what was already established through Christ. In this regard it is also interesting that a what a person does, can be considered in public, while a person's faith is a private matter between him- or herself and God.

In the African view the being and identity of things are defined in terms of the force they possess, and this force is known as a potential for action. "A being is defined by what it can do, rather than by what it is" (Ruch 1981:149). Unlike in Western culture, an entity is therefore not understood as having a passive inherent essence which is present for our cognisance, but rather as having the potential for doing something which can only be experienced in the effect it has on us. The self that experiences the world is not detached from the world, but rather exists as an extension of the world (Anyanwu 1981:172). The self is viewed as one of the forces with potential for action. It only experiences itself in as far as the world affects it, and as far as it affects the world. "Man is man in the way he acts, reacts and is acted upon by events, that is, in the way he is interwoven into the multiplicity of events" (Anyanwu 1981:87). While the world is understood as the continuous interaction of invisible spiritual forces, the self is understood as one of these forces in the network of interaction. And, in as far as the self is understood as force (potential for action) another self can, like everything else, only be experienced in terms of its effect - in terms of what it does. In Pentecostalism a person's identity is also determined by what others experience that person to be and consequently by what a person does. Sometimes this view has been shared with us explicitly. At other times one could notice it in an indirect way trough the mediation of some other customs and activities. In this regard we may mention the custom to reveal one's sins and confessions to 
other people. Why should one's sins and confessions be proclaimed to other people? Is it because one's identity as a Christian is seen as being dependent on how other people regard you?

The Western notion of the self is that the self is an inner essence which is present for our cognisance inside ourselves. In the African view the self only exists in as far as it participates in the world of things, spirits and other people. These different perspectives on self hood is neatly illustrated by the following two statements made by a Western person and African person respectively:

I shall now close our eyes, I shall stop our ears, I shall call away all our senses, I shall efface even from our thoughts all the images of corporeal things, or at least I shall esteem them as vain and false; and thus holding converse only with ourselves and considering our own nature, I shall try little by little to reach a better knowledge of, and a more familiar acquaintanceship with ourselves (Descartes 1911:157).

The ontological relationships among life-forces do not permit the African to see things in isolation. In fact, he denies the existence of an individual as an isolated entity unrelated to others. He affirms the ontological relationship as the ultimate nature of things (Anyanwu 1981:90).

The African self exists as force, which can only be known in terms of its effects in a certain context. Therefore the African self can only be known, can only exist, in as far as its experiences has an effect on others. And, this self only comes to know itself as self, through the knowledge that it is experienced as a constant force by others Nsamenang 1999:29).

There is, however, also a very important difference between the traditional African and Pentecostal view of selfhood. In the ATWV a person's identity is not only determined by actions which are performed freely. A person's actions is rather viewed as the expression of his or her life-force. As we have seen, this life-force is understood as part of a relatively fixed structure of spiritual forces, and are often determined by other spirits which is more powerful than the individual. In the Pentecostal view a person's actions and identity can also be determined by spiritual forces like demons, but the individual also have a say with regard to whether the Holy Spirit or demons have control over him or her. A person's identity is not 
seen as fixed. One can change, and one can also change in the eyes of the community. This perspective was clearly illustrated to us during sermon in a black MICC congregation with the theme: "Don't dwell on past things." The message of this sermon was clear: One can change and become a different person by choosing to act differently.

\subsection{Morality}

Related to the hierarchical structure of Pentecostal congregations, is the phenomenon that their moral values usually take the from of a more or less fixed set of rules. These rules are determined by the pastor and the tradition that endorses the pastor with his authority. In this regard there is no room for individual and critical thought. No grey areas is, for instance, allowed with regard to the use of alcohol. The rule states simply that no alcohol is to be used, and that is that. In reformed churches moral decisions is to a greater extent left over to the discretion of the individual. The individual is, for instance, allowed more freedom with regard to deciding how much alcohol to consume. This aspect of Pentecostalism is clearly illustrated when one compare the statement of the Pentecostal pastor we quoted above with the following statement by a URC reverent concerning the consumption of alcohol.

If you use too much alcohol it is a sin, but "too much" is also relative to a particular person. For me it might be two beers and for another man six. One cannot make a definitive rule in this regard (URC reverent).

This view is clearly in opposition to the view, expressed by many Pentecostals, that there are no room for relativity and the discretion of the individual when it comes to the determining what is right and what is wrong.

Because the Western self is an internal and autonomous reality, it can function as the centre of moral impulse and responsibility. The African self, however, is established by external factors and can only have an existence in as far as the effects of its actions can be experienced by a community. African morality is therefore not regulated by an internal autonomous unit and its conscience, but by external principles and forces which are determined by the natural hierarchy of spiritual forces, and the way in which these forces have been culturally defined within a particular African community (Crafford 1996:19). Unlike Western ethics, 
African ethics does not involve original internal reflection, but consists solely of clearly defined cultural rules or taboos (Crafford 1996:6,19). Like in traditional African communities, the individual's activities are regulated by sharply defined and very strict rules in the case of Pentecostal congregations. Pentecostals would view the use of alcohol as absolutely wrong, and no space is allowed for individual decisions and responsibility in this regard. Moreover, this strict set of rules does not receive its authority or legitimacy from the consensus reached within a community of relatively free thinkers. It rather receives its authority from the proclamations of the pastor, who again finds his authority from the fact that he is able to interpret the scripture in an authoritative way. In our view, these strict rules with regard to morality are guarded by a very simplistic way of interpreting scripture. There seems to be a total lack of hermeneutic consciousness in these churches. Scripture is simply taken to mean exactly what a pastor (or church member) at a specific moment (and informed by oral tradition) takes it to mean.

\begin{tabular}{|c|c|}
\hline PENTECOSTALISM & ATWV \\
\hline Cosmology: & \\
\hline $\begin{array}{l}\text { 1. experience the effect of divine and } \\
\text { evil spiritual forces during the course } \\
\text { of everyday life } \\
\text { 2. effect divine and other spiritual forces } \\
\text { by means of magical rituals. } \\
\text { 3. understand the holy spirit as a divine } \\
\text { force which empowers the believer. }\end{array}$ & $\begin{array}{l}\text { 1. experience the effect of divine and } \\
\text { evil spiritual forces during the course } \\
\text { of everyday life } \\
\text { 2. effect divine and other spiritual } \\
\text { forces by means of magical ritiuals } \\
\text { 3. believe that god is present in every } \\
\text { person as a vital life force. }\end{array}$ \\
\hline $\begin{array}{l}\text { Personhood: } \\
1 \text { believe a person's identity to be de- } \\
\text { pendent on his or her public perfor- } \\
\text { mance } \\
2 \text { believe that a person's actions and } \\
\text { identity are influenced by external } \\
\text { forces, but that a person still have the } \\
\text { ability to change who he or she is. }\end{array}$ & $\begin{array}{l}1 \text { believe a person's identity to be } \\
\text { dependent on the way in which } \\
\text { others experience him or her. } \\
\text { believe that a person's actions and } \\
\text { identity are determined by the } \\
\text { relatively fixed life-force that he or } \\
\text { she possesses. }\end{array}$ \\
\hline $\begin{array}{l}\text { Morality is determined by a strict set of } \\
\text { rules which is established by tradition and } \\
\text { enforced by a hierarchy of pastors. }\end{array}$ & $\begin{array}{l}\text { Morality is determined by a strict set of } \\
\text { rules which is established by tradition on } \\
\text { the grounds of a hierarchy of spiritual } \\
\text { forces, and which is enforced by a hier- } \\
\text { archical social structure. }\end{array}$ \\
\hline $\begin{array}{l}\text { Find strength and meaning in the } \\
\text { experience of community with one- } \\
\text { another, god and the power of god's spirit } \\
\text { through music and dance. }\end{array}$ & $\begin{array}{l}\text { Find strength and meaning in the } \\
\text { experience of harmony between one-self, } \\
\text { the community, god and the universe } \\
\text { through music and dance. }\end{array}$ \\
\hline
\end{tabular}

Diagram 2: Comparison between Pentecostalism and the ATWV 


\section{A HYPOTHESIS WHICH REQUIRES FURTHER INVESTIGATION}

What is the significance of these continuities and discontinuities between Pentecostalism and the traditional African world view in a context of urbanization? We do not pretend to be able to answer this question exhaustively after only one investigation. Certain possibilities may however be pointed out in this regard.

How does an African from a rural area experience his or her new life in the city? What challenges is he or she faced with? These questions must first be answered before we can establish the contribution of Pentecostal congregations towards the lives of these people. We asked these questions to people who have firsthand experience with the effect of urbanization on people who move into Witbank. One of the described the situation as follows:

Witbank is known as a place of mines and industry, so many people come here from the rural areas to look for jobs. But there just isn't enough jobs available here, so they end up being poor here. These things also lead to more crime. An immoral lifestyle is also a great cause of poverty. It also is easy for young girls to end up as prostitutes because of the lack of job opportunities. Mpumalanga is the province in South Africa with the second highest number of prostitutes, and Witbank is second only to Nelspruit with regard to the number of prostitutes. (AFM pastor). These remarks present us with at least one problem which is addressed by Pentecostalism. Traditional African morality functions well in the protective context of traditional society, but when these traditional social structures break down, like in modern urban society, Africans find it difficult to adjust in order to meet the challenges posed by the variety of life and range of choices in modern urban society. Problems such as excessive use of alcohol and drugs, gambling, debt, HIV/AIDS and crime which is experienced in the urban townships, might be related to the destruction of traditional social structures, and the morality it endorsed and protected. In Pentecostalism morality is also based on a strict set of rules which is enforced and endorsed by a hierarchical social structure. Pentecostal congregations function as new social environments which help people who come from the rural areas to live in a responsible and moral way. Pentecostalism's stress on the individual's capability to change his or her own way of life may also 
contribute towards establishing personal responsibility in the lives of people who are not used to making difficult moral decisions on their own.

Another problem Africans face when they leave traditional society to come and live in the city, is the fact that the economical practices and values of Western urban society differ from the economical rules of traditional African society. Africans may then find the things that are expected of them confusing, which in turn causes distress.

Yes, urbanisation and African culture doesn't go together well. In African culture people are used to living from the land. You don't buy eggs and milk, because nature provides it. Now people have to earn money in order to buy all these things. In the city you only have a small piece of land, so you cannot look after yourself with cattle and chickens. There are also many laws and regulations which make it difficult for people. You cannot just sell milk or meat, because everything must be tested and regulated (URC member: 22/06/2004).

Because Pentecostalism have much in common with the ATWV, they are able to make African feel at home in the strange environment of urban society. In Western society economical decisions are based on secular factors, like whether there is a market for products or not. In the ATWV decisions are often made on the bases of spiritual factors and help is often sought from magicians rather than from economists. Pentecostalism accommodate these perspectives by blessing people's businesses and by performing magical rituals.

These two examples at least indicate the possibility that Pentecostalism can assist Africans in the urbanization process, because it is so compatible with traditional African beliefs and values. Many more continuities between the traditional African world view and Pentecostalism have been indicated in this article, with the implication that the examples we have mentioned may just be the tip of the ice berg. Much more research is needed to understand the full extend of the impact that Pentecostalism have on the lives of people who move to the city from rural areas. Pentecostals may be playing a key role in providing social stability, solidarity and meaning to many South Africans who are faced with the challenges posed by urbanization and modernization. 


\section{Consulted literature}

Anyanwu, K C 1981. The African world-view and theory of knowledge, in: African Philosophy. Ruch, E A \& Anyanwu, K C. Rome: Catholic Book Agency, 77-99.

-, 1981. African religious experience, in African Philosophy. Ruch, E A \& Anyanwu, K C. Rome: Catholic Book Agency, 161-176.

-, 1981. Artistic and aesthetic experience, in African Philosophy. Ruch, E A \& Anyanwu, K C. Rome: Catholic Book Agency, 270-282.

Berger, P L 1977. Facing up to Modernity. New York: Penguin Books.

Crafford, D 1996. Traditional religions in Africa, in: South Africa: Country of many religions. Meiring, P (ed). Pretoria: Kagiso Publishers.

Crafford, D \& Gous, G 1993. One body - Many members. Pretoria: Verba Vitae.

Descartes, R 1911. Meditations on first philosophy, in The philosophical works of Descartes (vol 1). tr by Haldane, E S and Ross, G R T. Cambridge: Cambridge University Press.

Hollenweger, W 1974. Pentecost between Black and White. Belfast (Ireland): Christian Journals Limited

Mboya, M M. Culture and Self from an African perspective. Pretoria: Ilitha Publishers.

Ruch, E A 1981. In: African Philosophy. Ruch, E A \& Anyanwu, K C. Rome: Catholic Book Agency.

Theron, F T 1996. African Traditional Cultures and the Church. Pretoria: Institute for Missiological and Ecumenical Research, University of Pretoria. 